\title{
STATUS MUTU AIR PELABUHAN PANGGULUBELO \\ BERDASARKAN INDEKS STORET DAN INDEKS PENCEMARAN
}

\section{WATER QUALITY STATUS OF PANGGULUBELO HARBOUR BASED ON STORET INDEX AND POLLUTION INDEX}

\author{
Sunarwan Asuhadi ${ }^{1}$ dan Abdul Manan ${ }^{2}$ \\ ${ }^{1}$ Loka Perekayasaan Teknologi Kelautan (LPTK) BRSDM KP Kementerian Kelautan dan Perikanan \\ ${ }^{2}$ Fakultas Kehutanan dan Ilmu Lingkungan (FHIL) Universitas Halu Oleo \\ e-mail : sunarwan_asuhadi@yahoo.com \\ Diterima tanggal: 18 Januari 2018 ; diterima setelah perbaikan: 16 Agustus 2018 ; Disetujui tanggal: 30 Agustus 2018
}

\begin{abstract}
ABSTRAK
Metode penentuan status mutu air dapat menggunakan Indeks Storet dan Indeks Pencemaran. Penelitian ini bertujuan untuk mendapatkan gambaran tentang status mutu air laut Pelabuhan Panggulubelo. Teknik pengumpulan data dilakukan dengan pengambilan dan pengukuran kualitas sampel air laut, selain itu dikumpulkan publikasi tahun 2013 s.d. 2015 (time series) yang terkait dengan kualitas air laut di lokasi Pelabuhan Panggulubelo. Penentuan status mutu air menggunakan analisis Indeks Storet dan Indeks Pencemaran. Hasil pengukuran kualitas perairan menurut Indeks Storet menunjukkan skor -14 (tercemar sedang), sedangkan nilai Indeks Pencemaran adalah 2,79 (tercemar ringan). Ini menunjukkan bahwa perairan Pelabuhan Panggulubelo telah mengalami cemaran ringan dan sedang, serta memiliki potensi untuk mengalami pencemaran dengan status tercemar berat bilamana tidak dilakukan upaya yang tepat untuk mengurangi berbagai sumber pencemaran di area pelabuhan.
\end{abstract}

Kata kunci: Status mutu air, Pelabuhan Panggulubelo, indeks storet, indeks pencemaran.

\begin{abstract}
The water quality status identification can use the Storet Index and the Pollution Index. This study aimed to obtain an indication of sea water quality status Panggulubelo harbour. The data collection technique was carried out by collecting and measuring the quality of seawater samples. Several literature of past water quality status has been collected as secondary data, for further analysis. Determination the water quality status using Storet Index and Pollution Index analysis. The result of water quality measurement according to Storet Index showed the score -14 (fairly polluted), while Pollution Index value was 2.79 (lightly polluted). This indicated that the sea waters of Panggulubelo harbor have lightly and fairly contamination, and potential to have pollution contamination with heavily polluted status when no appropriate effort is developed to reduce various sources of pollution in the harbour area.
\end{abstract}

Keywords: Water quality status, Panggulubelo Harbour, storet index, pollution index.

Status Mutu Air Pelabuhan Panggulubelo Berdasarkan Indeks Storet dan Indeks Pencemaran - Sunarwan Asuhadi dan 


\section{PENDAHULUAN}

Pelabuhan Panggulubelo yang terletak di Kecamatan Wangi-Wangi Selatan merupakan salah satu pelabuhan paling ramai di Kabupaten Wakatobi. Kawasan pelabuhan ini berdekatan dengan area pemukiman penduduk di wilayah Kota Wangi-Wangi. Sejumlah kapal yang memanfaatkan jasa pelabuhan ini, di antaranya: KM Leuser dan KM Kelimutu, KFC Jetliner, kapal tol laut, dan kapal barang lokal. Meningkatnya aktivitas kapal di pelabuhan ini memengaruhi meningkatnya volume buangan yang mengandung minyak (oil waste). Pencemaran limbah ini, jika tidak segera ditangani akan merusak lingkungan perairan pelabuhan. Ini dikarenakan garis pantai atau pelabuhan adalah pusat berkembangbiaknya sebagian besar populasi hewan laut dan burung laut, bila dibandingkan di laut terbuka.

Kawasan Pelabuhan Panggulubelo memiliki implikasi yang sangat strategis bagi masyarakat Wakatobi, oleh karena masyarakat Wakatobi banyak bergantung pada fungsi-fungsi laut untuk berbagai kebutuhan pembangunan, khususnya pada sektor perikanan dan kelautan. Perikanan adalah semua kegiatan yang terorganisir berhubungan dengan pengelolaan dan pemanfaatan sumberdaya ikan dan lingkungannya mulai dari praproduksi, produksi, pengolahan sampai dengan pemasaran, yang dilaksanakan dalam suatu sistem bisnis perikanan (UU Nomor 31 Tahun 2004).

Istilah 'kelautan' merujuk pada Kamus Besar Bahasa Indonesia (KBBI) berasal dari kata "laut" yang mempunyai arti hamparan air asin dalam jumlah yang banyak dan luas menggenangi dan membagi daratan atas benua atau pulau. Dari definisi itu pengertian kelautan lebih dapat dilihat dari segi fisikal atau bentuk fisiknya, sedangkan maritim dalam KBBI didefinisikan sebagai berkenaan dengan laut, berhubungan dengan pelayaran dan perdagangan di laut. Dengan demikian, dapat disimpulkan bahwa kemaritiman mempunyai definisi yang tidak terfokus dari segi fisik (physical property) tapi lebih luas lagi, yaitu dengan memasukkan unsur non fisik, seperti pelayaran dan perdagangan di laut.

Pada kegiatan operasional sebuah kapal, apapun tipenya, sulit sekali untuk dapat menghindari sumbersumber yang memungkinkan terjadinya pencemaran minyak ke laut di sekitarnya. Hal itu makin diperparah oleh para operator kapal yang tidak mempunyai kesadaran dan tindakan dalam mencegah terjadinya pencemaran buangan-buangan kapal di laut.
Instrument yang dapat digunakan untuk menggambarkan status mutu air Pelabuhan Panggulubelo adalah Indeks Storet dan Indeks Pencemaran Air, sebagaimana diatur pada Keputusan Menteri Negara Lingkungan Hidup Nomor: 115 Tahun 2003 tentang Pedoman Penentuan Status Mutu Air. Dengan menggunakan instrument ini dapat menjadi dasar untuk mengetahui kondisi perairan pelabuhan, baik tercemar ataupun dalam kondisi baik.

Penelitian ini dimaksudkan untuk menentukan nilai mutu air laut, dan mendapatkan gambaran terhadap tingkat status mutu air laut Pelabuhan Panggulubelo. Dengan mengetahui status mutu air pelabuhan tersebut diharapkan akan memberikan gambaran terhadap pilihan tindakan yang tepat dalam pengelolaan Pelabuhan Panggulubelo.

\section{BAHAN DAN METODE}

\section{Waktu dan Lokasi Penelitian}

Penelitian ini dilaksanakan di Pelabuhan Panggulubelo Kecamatan Wangi-Wangi Selatan Kabupaten Wakatobi. Lokasi penelitian berada pada posisi koordinat:

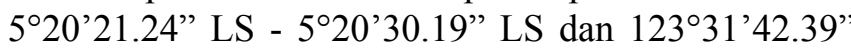
BT - 12331'51.70” BT. Penelitian ini dilaksanakan pada Juni 2017 sampai dengan Agustus 2017. Lokasi selengkapnya dapat dilihat pada Gambar 1.

\section{Metode Penelitian}

Penelitian ini adalah penelitian kuantitatif, teknik pengumpulan data dilakukan dengan pengambilan dan pengukuran kualitas sampel air laut di lokasi yang dimaksud, selain itu juga dilakukan desk study. Adapun metode penentuan status mutu air Pelabuhan Panggulubelo menggunakan Metode Storet dan Metode Indeks Pencemaran, sebagaimana disebutkan pada Keputusan Menteri Negara Lingkungan Hidup, Nomor: 115 Tahun 2003 tentang Pedoman Penentuan Status Mutu Air.

Pengukuran status mutu air dengan menggunakan Indeks Storet dan Indeks Pencemaran, dapat menunjukkan perbedaan tingkat sensitivitas keduanya dalam menggambarkan kualitas suatu badan perairan, yakni melalui tingkat toleransi kedua indeks tersebut terhadap kualitas suatu badan perairan.

Penentuan status mutu air dengan metode Storet adalah dengan membandingkan data kualitas air dengan baku mutu yang disesuaikan dengan peruntukannya. 


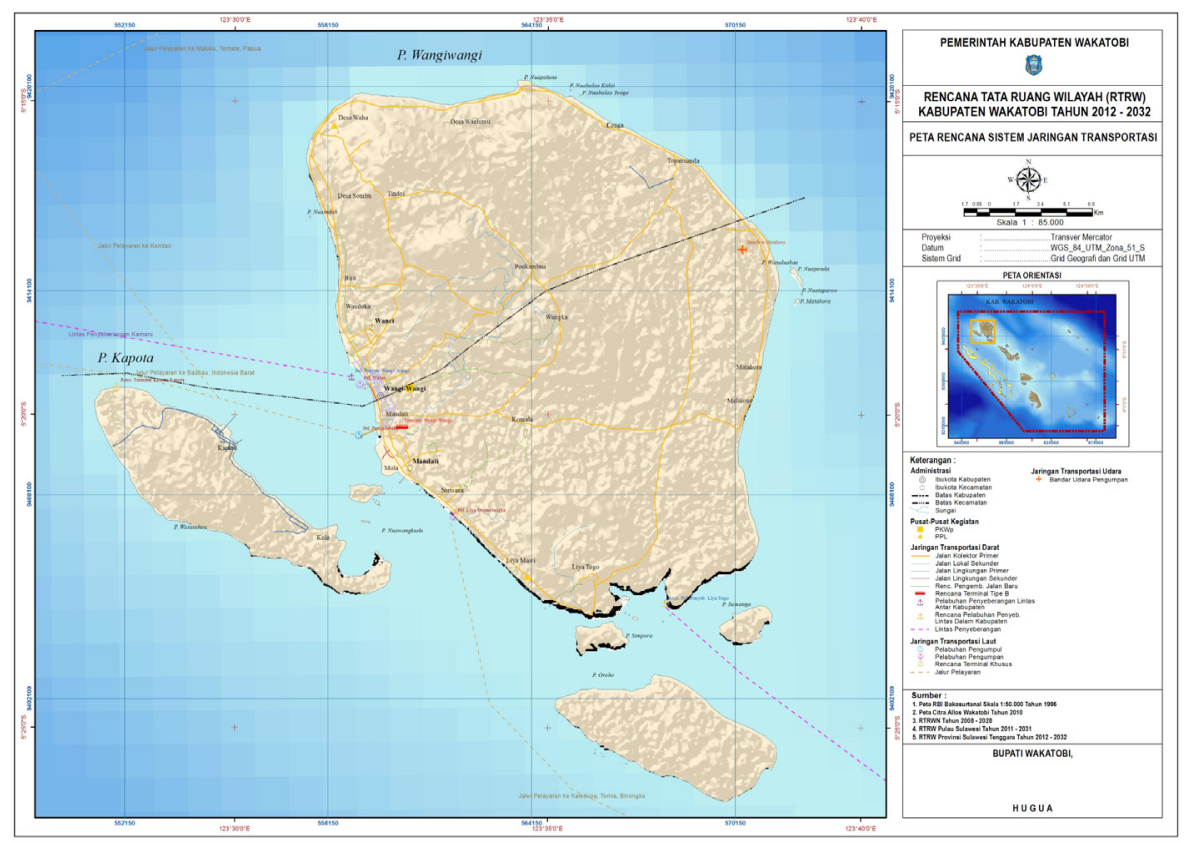

Gambar 1. Peta Lokasi Penelitian.

Figure 1. Map of Research Location.

Sumber: Album Peta RTRW Kab. Wakatobi, 2012

Awalnya metode Storet dikembangkan untuk menilai mutu air untuk "specific use" misal peruntukan air minum. Namun belakangan metode tersebut juga dapat dipakai untuk menilai "overall use" air. Penentuan status mutu air menggunakan time series data. Jika hasil pengukuran memenuhi nilai baku mutu maka diberi skor $=0$, sedang jika hasil pengukuran melampaui baku mutu maka diberi skor sebagaimana disebutkan pada Tabel 1. Status mutu air diklasifikasikan dalam 4 kelas, kelas A : baik sekali/memenuhi baku mutu, skor 0; kelas B : baik/tercemar ringan, skor -1 sampai -10 ; kelas $\mathrm{C}$ : sedang/tercemar sedang, skor -11 sampai dengan -30; kelas D : buruk/ tercemar berat, skor $\leq-31$.
Metode Indeks Pencemaran (IP) (Nemerow \& Sumitomo, 1970) ini digunakan untuk menentukan tingkat pencemaran relatif terhadap parameter kualitas air yang diijinkan dengan rumus sebagai berikut,

$$
I P_{j}=\sqrt{\frac{\left(\frac{C_{i}}{L_{i j}}\right)_{M}^{2}+\left(\frac{C_{i}}{L_{i j}}\right)_{R}^{2}}{2}}
$$

dimana IPj adalah indeks pencemaran bagi peruntukan j, Ci adalah konsentrasi parameter kualitas air i, Lij adalah konsentrasi parameter kualitas air i yang tercantum dalam baku peruntukan air $\mathrm{j}, \mathrm{M}=$ maksimum, $\mathrm{R}=$ rerata.

Tabel 1. Skor Masing-Masing Jenis Parameter dalam Metode Storet Table 1. Score of Each Parameter Type in the Storet Method

\begin{tabular}{lllll}
\hline \multirow{2}{*}{ Jumlah Parameter $^{*}$} & Nilai & \multicolumn{3}{c}{ Parameter } \\
& & Fisika & Kimia & Biologi \\
\hline \multirow{4}{*}{$<10$} & Maks & -1 & -2 & -3 \\
& Min & -1 & -2 & -3 \\
& Rerata & -3 & -6 & -9 \\
& & & & \\
& Maks & -2 & -4 & -6 \\
& Min & -2 & -4 & -6 \\
& Rerata & -6 & -12 & -18 \\
\hline
\end{tabular}

Sumber: KepMen LH No KEP 115/MENLH/2003

Catatan * : jumlah parameter yang digunakan untuk menghitung Indeks Kualitas Air 
Jika nilai konsentrasi parameter yang menurun menyatakan tingkat pencemaran meningkat, misal DO. Maka ditentukan nilai teoritik atau nilai maksimum Cim (misal untuk DO, maka Cim merupakan nilai DO jenuh). Dalam kasus ini nilai $\mathrm{Ci} / \mathrm{Lij}$ hasil pengukuran digantikan oleh nilai $\mathrm{Ci} / \mathrm{Lij}$ hasil perhitungan, yaitu:

$$
\left(\frac{C i}{\text { Lij }}\right) \text { baru }=\frac{C_{i m}-C_{i} \text { hasil pengukuran }}{C_{i m}-L_{i j}}
$$

Jika nilai baku Lij memiliki rentang

- untuk $\mathrm{Ci} \leq \mathrm{Lij}$ rata-rata

$$
\left(\frac{C i}{\text { Lij }}\right) \text { baru }=\frac{\left[C_{i}-\left(L_{i j}\right)_{\text {rata-rata }}\right]}{\left\{\left(L_{i j}\right)_{\text {minimum }}-\left(L_{i j}\right)_{\text {rata-rata }}\right\}}
$$

- untuk $\mathrm{Ci}>$ Lij rata-rata

$$
\left(\frac{C i}{\text { Lij }}\right) \text { baru }=\frac{\left[C_{i}-\left(L_{i j}\right)_{\text {rata-rata }}\right]}{\left\{\left(L_{i j}\right)_{\text {maksimum }}-\left(L_{i j}\right)_{\text {rata-rata }}\right\}}
$$

Keraguan timbul jika dua nilai (Ci/Lij) berdekatan dengan nilai acuan 1,0 , misal $\mathrm{C} 1 / \mathrm{L} 1 \mathrm{j}=0,9$ dan $\mathrm{C} 2 /$ $\mathrm{L} 2 \mathrm{j}=1,1$ atau perbedaan yang sangat besar, misal C3/ $\mathrm{L} 3 \mathrm{~J}-5,0$ dan $\mathrm{C} 4 / \mathrm{L} 4 \mathrm{j}=10,0$. Dalam contoh ini tingkat kerusakan badan air sulit ditentukan. Cara untuk mengatasi kesulitan ini adalah :

1. Penggunaan nilai $(\mathrm{Ci} / \mathrm{Lij})$ hasil pengukuran kalau nilai ini lebih kecil dari 1,0 .

2. Penggunaan nilai $(\mathrm{Ci} / \mathrm{Lij})$ baru jika nilai $(\mathrm{Ci} / \mathrm{Lij})$ hasil pengukuran lebih besar dari 1,0.

$$
\left(\frac{C i}{L i j}\right) \text { baru }=1,0+P \cdot \log \left(\frac{C i}{L i j}\right) \text { hasil pengukuran }
$$

Indeks kualitas air IP ditentukan dari resultante nilai maksimum dan nilai rerata rasio konsentrasi per paramater terhadap nilai baku mutunya. Untuk satu target peruntukan/pemanfaatan air, semua nilai relatif pencemaran tidak diberi bobot, pembobotan dilakukan saat menghitung IP dari n jumlah pemanfatan air (misal kelompok human/direct contact untuk air minum dan lainnya, kelompok remote contact untuk navigasi dan lainnya, kelompok indirect contact untuk pertanian dan lainnya), dengan rumus:

$$
I P=\sum_{j=1}^{j=n} w_{j} I P_{j} \quad \text { dan } \sum_{j=1}^{j=n} w_{j}=1
$$

dimana wj adalah bobot masing-masing jenis penggunaan air. Kelas indeks IP ada 4 dengan skor $0 \leq$ IP $\leq 1,0$ adalah memenuhi baku mutu (good); $1,0<$ IP $\leq 5,0$ tercemar ringan (slightly polluted) $; 5,0<$ IP $\leq 10$ tercemar sedang (fairly polluted), IP $>10,0$ dengan status perairan tercemar berat (heavily polluted).

Adapun Baku Mutu Perairan Laut yang digunakan untuk menentukan status mutu air perairan Pelabuhan Panggulubelo adalah Keputusan Menteri Negara Lingkungan Hidup Nomor 51 Tahun 2004 tentang Baku Mutu Air Laut dengan peruntukkan pelabuhan.

\section{HASIL DAN PEMBAHASAN}

\section{Struktur Data yang Digunakan untuk Pengukuran Indeks}

Data yang digunakan untuk pengukuran Indeks Storet dan Indeks Pencemaran merupakan data time series sejak tahun 2013, 2015, dan 2016. Untuk data tahun 2013 dan 2015 merupakan data sekunder, sedangkan data 2016 adalah data primer. Adapun data yang dimaksud sebagaimana ditunjukkan pada Tabel 2.

Secara umum, kualitas perairan Pelabuhan Panggulubelo berdasarkan parameter yang diukur dari tahun 2013 s.d. tahun 2016 cenderung dinamis. Parameter yang mengalami fluktuasi tercemar, yakni TSS dalam mg/L $(127,5 ; 1,52 ; 160)$, parameter yang sebelumnya tercemar menjadi baik (tidak tercemar), yakni $\mathrm{pH}(8,53 ; 7,9 ; 6,3)$ dan ammonia dalam $\mathrm{mg} / \mathrm{L}(8,5$; $0,04 ; 0.3)$, serta parameter yang kondisi perubahannya relatif baik (tidak tercemar), yakni minyak dan lemak dalam $\mathrm{mg} / \mathrm{L}(5 ; 2,64 ; 0,6)$, kadmium dalam $\mathrm{mg} / \mathrm{L}$ $(0,006,<0.0006,0.0014)$, tembaga dalam $\mathrm{mg} / \mathrm{L}(0.0085$, $<0.006,0.0069)$, raksa dalam $\mathrm{mg} / \mathrm{L}(0,0008 ;<0,0008$; $0,0001)$, timbal dalam $\mathrm{mg} / \mathrm{L}(<0,0001 ;<0,006 ; 0,0008)$, dan coliform dalam MPN/100 ml ( $0 ; 240 ; 0)$.

Dari data yang tersedia, yang dapat digunakan secara komparatif untuk pengukuran indeks pencemaran sebanyak $10<$ parameter, yang merupakan gabungan dari seluruh parameter fisika, kimia, dan biologi. Adapun parameter komparatif yang digunakan sebagaimana ditunjukkan pada Tabel 3.

Sampel data di atas diambil pada November 2013, Desember 2015 dan November 2016. Kesamaan pengambilan sampel adalah dilakukan pada periode awal Musim Barat, di mana Musim Barat terhitung sejak bulan Oktober - April setiap tahunnya.

Tingginya konsentrasi Total Padatan Tersuspensi, Derajat Keasaman, dan Ammonia pada tahun 2013, diduga dipengaruhi oleh dekomposisi sampah bahan organik yang berasal dari lingkungan pemukiman 
Tabel 2. Kualitas Air Perairan Pelabuhan Panggulubelo 2013 - 2016

Table 2. Water Quality of Panggulubelo Port Waters in 2013-2016

\begin{tabular}{|c|c|c|c|c|c|c|}
\hline \multirow[t]{2}{*}{ No } & \multirow[t]{2}{*}{ Parameter } & \multirow[t]{2}{*}{ Baku Mutu } & \multirow[t]{2}{*}{ Satuan } & \multicolumn{3}{|c|}{ Data Kualitas Air } \\
\hline & & & & $\left.2013^{*}\right)$ & $\left.2015^{* *}\right)$ & $\left.2016^{* * *}\right)$ \\
\hline A & FISIKA & & & & & \\
\hline \multirow[t]{2}{*}{1} & \multirow[t]{2}{*}{ Kecerahan (In situ) } & coral: $>5$ & & & & \\
\hline & & $\begin{array}{l}\text { mangrove: - } \\
\text { lamun: }>3\end{array}$ & $\mathrm{~m}$ & - & 1,50 & - \\
\hline \multirow{3}{*}{$\begin{array}{l}2 \\
3\end{array}$} & \multirow{3}{*}{$\begin{array}{l}\text { Kebauan } \\
\text { Zat Padat Tersuspensi (TSS) }\end{array}$} & Tidak berbau & - & - & Tidak berbau & - \\
\hline & & coral: $>20$ & & & & \\
\hline & & $\begin{array}{l}\text { mangrove: } 80 \\
\text { lamun: }>20\end{array}$ & $\mathrm{mg} / \mathrm{L}$ & 127.5 & 1,52 & 160 \\
\hline 4 & Total Padatan Terlarut & - & $\mathrm{mg} / \mathrm{L}$ & 25,090 & - & - \\
\hline 5 & Kekeruhan & - & NTU & - & - & 1,05 \\
\hline 6 & Suhu air & - & ${ }^{\circ} \mathrm{C}$ & 31,67 & 33,9 & - \\
\hline 7 & Lapisan Minyak & Nihil & - & - & Nihil & - \\
\hline 8 & Sampah (In situ) & Nihil & - & - & Nihil & - \\
\hline B & KIMIA & - & - & - & - & - \\
\hline 1 & pH (In situ) & $6,5-8,5$ & - & 8,53 & 7,9 & 6,30 \\
\hline 2 & Salinitas Alami & & $\%$ & & 0,28 & 29 \\
\hline 3 & $\mathrm{DO}$ & $>5$ & $\mathrm{mg} / \mathrm{L}$ & 10,50 & - & 0,0001 \\
\hline 4 & BOD & 20 & $\mathrm{mg} / \mathrm{L}$ & 1,22 & - & - \\
\hline 5 & Ammonia total (NH3-N) & 0,3 & $\mathrm{mg} / \mathrm{L}$ & 8,5 & 0,04 & 0,3 \\
\hline 6 & Nitrat & 0,008 & $\mathrm{mg} / \mathrm{L}$ & 0,94 & - & - \\
\hline 7 & Nitrit & - & $\mathrm{mg} / \mathrm{L}$ & $<0,02$ & - & - \\
\hline 8 & COD & - & $\mathrm{mg} / \mathrm{L}$ & 350 & - & - \\
\hline 9 & Sulfida (H2S) & 0,03 & $\mathrm{mg} / \mathrm{L}$ & - & 0,02 & - \\
\hline 10 & Fhosfat & 0,015 & $\mathrm{mg} / \mathrm{L}$ & 11 & - & - \\
\hline 11 & Fenol & 0,002 & $\mathrm{mg} / \mathrm{L}$ & - & 0,05 & - \\
\hline 12 & Surfactan anion (MBAS) & 1,0 & $\mathrm{mg} / \mathrm{L}$ & - & 0,02 & - \\
\hline 13 & Minyak \& Lemak & 5,0 & $\mathrm{mg} / \mathrm{L}$ & 5,0 & 2,64 & 0,60 \\
\hline 14 & Belerang & 0,01 & $\mathrm{mg} / \mathrm{L}$ & 0,0001 & - & - \\
\hline 15 & Detergen & 1 & $\mathrm{mg} / \mathrm{L}$ & $<0,002$ & - & - \\
\hline 16 & Sianida & 0,5 & $\mu \mathrm{g} / \mathrm{L}$ & $<0,001$ & - & - \\
\hline 17 & Kobalt & - & $\mathrm{mg} / \mathrm{L}$ & 0,06 & - & - \\
\hline 18 & Air Raksa & 0,003 & $\mathrm{mg} / \mathrm{L}$ & 0,0008 & $<0,0008$ & 0,0001 \\
\hline 19 & $\left.\operatorname{Kadmium}(\mathrm{Cd})^{*}\right)$ & 0,01 & $\mathrm{mg} / \mathrm{L}$ & 0,006 & $<0,0006$ & 0,0014 \\
\hline 20 & Tembaga $\left.(\mathrm{Cu})^{*}\right)$ & 0,05 & $\mathrm{mg} / \mathrm{L}$ & 0,0085 & $<0,006$ & 0,0069 \\
\hline 21 & Timbal $\left.(\mathrm{Pb})^{*}\right)$ & 0,05 & $\mathrm{mg} / \mathrm{L}$ & $<0,0001$ & $<0,006$ & 0,0008 \\
\hline 22 & Seng $\left.(\mathrm{Zn})^{*}\right)$ & 0,1 & $\mathrm{mg} / \mathrm{L}$ & - & $<0,02$ & 0,0314 \\
\hline 23 & Hidrokarbon Total (HC) & 1 & $\mathrm{mg} / \mathrm{L}$ & - & $<1$ & \\
\hline 24 & Arsen & - & $\mathrm{mg} / \mathrm{L}$ & - & - & 0,0237 \\
\hline 25 & Krom val 6 & 0,005 & $\mathrm{mg} / \mathrm{L}$ & 0,008 & - & \\
\hline 26 & Nikel & - & - & - & - & 0,0014 \\
\hline $\mathrm{C}$ & MIKROBIOLOGI & - & - & - & - & \\
\hline 1 & E-Colli & Negatif & - & 0 & - & Negatif \\
\hline 2 & Coli tinja & 0 & MPN/100 mL & - & - & 0 \\
\hline 3 & Coliform (total) & 1000 & MPN/100ml & - & 240 & 0 \\
\hline
\end{tabular}

Keterangan:

*) Hasil Pengujian Kualitas Air Laut Laboratorium Kesehatan Prov. Sultra Tahun 2013 (SLHD Provinsi Sulawesi Tenggara)

**) Dokumen Rencana Usaha dan/atau Kegiatan UKL - UPL Pembangunan Pelabuhan Panggulubelo, hal. 2-53

***) Hasil Pengujian Kualitas Air Laut Laboratorium Kesehatan Prov. Sultra Tahun 2016 (Laporan Kegiatan MPA LPTK 2016) 
Tabel 3. Data Kualitas Air yang Digunakan untuk Pengukuran Indeks Pencemaran Table 3. Water Quality Data used For Measurement of Pollution Index

\begin{tabular}{llllllll}
\hline No & Parameter & Satuan & Baku Mutu & 2013 & $\mathbf{2 0 1 5}$ & 2016 & Rerata \\
\hline 1 & Total Padatan Tersuspensi & $\mathrm{mg} / \mathrm{L}$ & 20 & 127.5 & 1,52 & 160 & 96.34 \\
2 & Derajat Keasaman & $\mathrm{mg} / \mathrm{L}$ & $6,5-8,5$ & 8,53 & 7,9 & 6,3 & 7,58 \\
3 & Ammonia & $\mathrm{mg} / \mathrm{L}$ & 0,3 & 8,5 & 0,04 & 0,3 & 2,95 \\
4 & Minyak dan Lemak & $\mathrm{mg} / \mathrm{L}$ & 5 & 5 & 2,64 & 0,6 & 2,75 \\
5 & Kadmium & $\mathrm{mg} / \mathrm{L}$ & 0,01 & 0,006 & $<0,0006$ & 0,0014 & 0,0037 \\
6 & Tembaga & $\mathrm{mg} / \mathrm{L}$ & 0,05 & 0,0085 & $<0,006$ & 0,0069 & 0,0077 \\
7 & Raksa & $\mathrm{mg} / \mathrm{L}$ & 0,003 & 0,0008 & $<0,0008$ & 0,0001 & 0,00045 \\
8 & Timbal & $\mathrm{mg} / \mathrm{L}$ & 0,05 & $<0,0001<0,006$ & 0,0008 & 0,0008 \\
9 & Coliform & $\mathrm{MPN} / 100 \mathrm{ml}$ & 1000 & 0 & 240 & 0 & 80 \\
\hline
\end{tabular}

Keterangan: Data di atas digunakan berdasarkan kesamaan parameter yang diukur

penduduk, buangan kapal, serta aktivitas jual beli bahan makanan di area pelabuhan pada saat pemberangkatan kapal (Kendari dan Baubau). Pada tahun 2015 dermaga pemberangkatan kapal (Kendari dan Baubau) dipindahkan ke area Pelabuhan Ferry yang berdampak pada membaiknya kondisi perairan pelabuhan. Namun, pada tahun 2016, konsentrasi Total Padatan Tersuspensi menjadi tinggi, kemungkinan selain disebabkan oleh dekomposisi sampah bahan organik yang berasal dari lingkungan pemukiman penduduk, buangan kapal, juga aktivitas penangkapan ikan oleh nelayan di sekitar perairan pelabuhan, juga kondisi pengambilan sampel air yang dilakukan pada waktu air laut surut.

\section{Kualitas Perairan Pelabuhan Panggulubelo Menurut Indeks Storet}

Indeks Storet merupakan salah satu instrument untuk mengukur kualitas ketercemaran suatu badan perairan dengan menggunakan data perbandingan antara data kualitas air dengan baku mutu air yang disesuaikan dengan peruntukannya guna menentukan status mutu air sebagaimana diatur pada Keputusan Menteri Negara Lingkungan Hidup, Nomor: 115 Tahun 2003 tentang Pedoman Penentuan Status Mutu Air.

Cara untuk menentukan status mutu air adalah dengan menggunakan sistem nilai dari "USEPA (Environmental Protection Agency)" dengan mengklasifikasikan mutu air dalam empat kelas, yaitu :

(1) Kelas A : baik sekali, skor $=0$ memenuhi baku mutu

(2) Kelas B : baik, skor $=-1 \mathrm{~s} / \mathrm{d}-10$ tercemar ringan

(3) Kelas C : sedang, skor $=-11 \mathrm{~s} / \mathrm{d}-30$ tercemar sedang

(4) Kelas D : buruk, skor $\geq-31$ tercemar berat

Kondisi kualitas Perairan Pelabuhan Panggulubelo menurut Indeks Storet (Tabel 4).

Hasil pengukuran kualitas perairan Pelabuhan Panggulubelo menurut Indeks Storet menunjukkan bahwa skoring Indeks Storet adalah -14. Berdasarkan klasifikasi Indeks Storet, skoring ini bermakna bahwa perairan Pelabuhan Panggulubelo terkategori Kelas C

Tabel 4. Kualitas Perairan Pelabuhan Panggulubelo menurut Indeks Storet

Table 4. Panggulubelo Port Water Quality according to the Storet Index

\begin{tabular}{|c|c|c|c|c|c|c|}
\hline \multirow[t]{2}{*}{ No. } & \multirow[t]{2}{*}{ Parameter } & \multirow[t]{2}{*}{ Sub Parameter } & \multicolumn{3}{|c|}{ Nilai } & \multirow[t]{2}{*}{ Skor } \\
\hline & & & Maks & Min & Rerata & \\
\hline 1 & Fisika & Total Padatan Tersuspensi & -1 & 0 & -3 & -4 \\
\hline 2 & Kimia & Derajat Keasaman & -2 & 0 & 0 & -2 \\
\hline 3 & & Ammonia & -2 & 0 & -6 & -8 \\
\hline 4 & & Minyak dan Lemak & 0 & 0 & 0 & 0 \\
\hline 5 & & Kadmium & 0 & 0 & 0 & 0 \\
\hline 6 & & Tembaga & 0 & 0 & 0 & 0 \\
\hline 7 & & Raksa & 0 & 0 & 0 & 0 \\
\hline 8 & & Timbal & 0 & 0 & 0 & 0 \\
\hline 9 & Biologi & Coliform & 0 & 0 & 0 & 0 \\
\hline & & Total skor & & & & -14 \\
\hline
\end{tabular}


atau sedang, di mana skor $=-11 \mathrm{~s} / \mathrm{d}-30$ diklasifikasikan sebagai tercemar sedang.

\section{Kualitas Perairan Pelabuhan Panggulubelo Menurut Indeks Pencemaran}

Selain Indeks Storet, Keputusan Menteri Negara Lingkungan Hidup, Nomor: 115 Tahun 2003 tentang Pedoman Penentuan Status Mutu Air juga memuat cara menentukan status mutu air dengan menggunakan Indeks Pencemaran.

Indeks Pencemaran berkaitan dengan senyawa pencemar. Indeks ini yang digunakan untuk menentukan tingkat pencemaran relatif terhadap parameter kualitas air yang diizinkan (Nemerow, 1974). Indeks ini memiliki konsep yang berlainan dengan Indeks Kualitas Air (Water Quality Index). IP ditentukan untuk suatu peruntukan, kemudian dapat dikembangkan untuk beberapa peruntukan bagi seluruh bagian badan air atau sebagian dari suatu badan air.

Pengelolaan kualitas air atas dasar IP ini dapat memberi masukan pada pengambil keputusan agar dapat menilai kualitas badan air untuk suatu peruntukan serta melakukan tindakan untuk memperbaiki kualitas jika terjadi penurunan kualitas akibat kehadiran senyawa pencemar. IP mencakup berbagai kelompok parameter kualitas yang independent dan bermakna. Status Mutu Air Laut berdasarkan Indeks Pencemaran ditunjukkan pada Tabel 5.

Hasil pengukuran kualitas perairan Pelabuhan Panggulubelo menurut Indeks Pencemaran menunjukkan bahwa nilai Indeks Pencemaran adalah 2,79. Berdasarkan klasifikasi Indeks Pencemaran, ini bermakna bahwa perairan Pelabuhan Panggulubelo terkategori dengan nilai $1,0<\operatorname{PIj} \leq 5,0$, atau diklasifikasikan sebagai tercemar ringan. Dengan demikian, ditemukan klasifikasi status mutu air yang berbeda antara penggunaan pengukuran Indeks Storet dan Indeks Pencemaran. Kedua instrumen pengukuran status mutu air tersebut menunjukkan bahwa perairan Pelabuhan Panggulubelo terkategori tercemar sedang dan ringan.

Sensivitas indeks berdasarkan hasil riset yang dilakukan oleh Sri Puji Saraswati, dkk. (2014) menunjukkan bahwa sensitivitas antara Indeks Storet dan Indeks Pencemaran dengan 17 parameter kualitas air, termasuk bakteriologi adalah sangat sensitif terhadap satu parameter (bakteriologi) dengan konsentrasi sangat tinggi relatif terhadap baku mutunya. Indeks Pencemaran dengan sedikit atau banyak parameter kualitas air (3, 4 atau 9 parameter tidak memenuhi baku mutu) tidak cukup sensitif membedakan kelas status mutu air di setiap lokasi sampel dan saat sampling kualitas airnya. Hal ini karena dalam metode PI, yang dianggap penting menentukan skor indeks PI adalah suatu parameter yang mempunyai $(\mathrm{Ci} / \mathrm{Lij})$

Tabel 5. Kualitas Perairan Pelabuhan Panggulubelo menurut Indeks Pencemaran

Table 4. Water Quality of Panggulubelo Port in accordance with Pollution Index

\begin{tabular}{|c|c|c|c|c|c|c|c|c|c|c|c|}
\hline No & Parameter & Ci1 & $\mathrm{Ci} 2$ & $\mathrm{Ci3}$ & Lij & Ci/Lij1 & $\mathrm{Ci} / \mathrm{Lij} 2$ & $\mathrm{Ci} / \mathrm{Lij3}$ & $\begin{array}{l}\text { Ci/Lij1 } \\
\text { baru }\end{array}$ & $\begin{array}{l}\text { Ci/Lij2 } \\
\text { baru }\end{array}$ & $\begin{array}{l}\mathrm{Ci} / \mathrm{Lij3} \\
\text { baru }\end{array}$ \\
\hline 1 & $\begin{array}{l}\text { Total Padatan } \\
\text { Tersuspensi }\end{array}$ & 127,5 & 1,52 & 160 & 20 & 6,38 & 0,076 & 8 & 5,0 & 0,076 & 5,52 \\
\hline 2 & $\begin{array}{l}\text { Derajat } \\
\text { Keasaman }\end{array}$ & 8,53 & 7,9 & 6,3 & $6,5-8,5$ & 1,03 & 0,67 & 1,20 & 1,1 & 0,67 & 1,40 \\
\hline 3 & Ammonia & 8,5 & 0,04 & 0,3 & 0,3 & 28,33 & 0,13 & 1 & 8,3 & 0,13 & 1 \\
\hline 4 & $\begin{array}{l}\text { Minyak dan } \\
\text { Lemak }\end{array}$ & 5 & 2,64 & 0,6 & 5 & 1 & 0,53 & 0,12 & 1 & 0,53 & 0,12 \\
\hline 5 & Kadmium & 0,006 & $<0,0006$ & 0,0014 & 0,01 & 0,6 & 0,06 & 0,14 & 0,6 & 0,06 & 0,14 \\
\hline 6 & Tembaga & 0,0085 & $<0,006$ & 0,0069 & 0,05 & 0,17 & 0,12 & 0,14 & 0,17 & 0,12 & 0,14 \\
\hline 7 & Raksa & 0,0008 & $<0,0008$ & 0,0001 & 0,003 & 0,27 & 0,27 & 0,03 & 0,27 & 0,27 & 0,03 \\
\hline 8 & Timbal & $<0,0001$ & $<0,006$ & 0,0008 & 0,05 & 0,002 & 0,12 & 0,016 & 0,002 & 0,12 & 0,016 \\
\hline 9 & Coliform & 0 & 240 & 0 & 1000 & 0 & 0,24 & 0 & 0 & 0,24 & 0 \\
\hline & & & & & \multirow{4}{*}{\multicolumn{3}{|c|}{$\begin{array}{l}\text { (Ci/Lij) Maksimum } \\
(\mathrm{Ci} / \text { Lij) Rata-rata } \\
\text { Pij } \\
\text { Pij Rata-rata }\end{array}$}} & & 8,3 & 0,67 & 2,51 \\
\hline & & & & & & & & & 1,8 & 0,25 & 0,93 \\
\hline & & & & & & & & & 5,98 & 0,50 & 1,89 \\
\hline & & & & & & & & & & 2,79 & \\
\hline
\end{tabular}

Status Mutu Air Pelabuhan Panggulubelo Berdasarkan Indeks Storet dan Indeks Pencemaran - Sunarwan Asuhadi dan 
maksimum, dibanding rerata semua parameter kualitas airnya. Sedangkan Indeks Storet cukup sensitif merespon dinamika indeks kualitas air di setiap lokasi dengan sedikit atau banyak parameter. Semakin banyak parameter kualitas air diukur semakin banyak terpantau parameter tidak memenuhi baku mutu (dari nilai maksimum dan minimum parameter) dan semakin sering parameter tersebut tidak memenuhi ambang batas, akan semakin jelek status mutu airnya. Akan tetapi status indeks Storet sangat dipengaruhi oleh bobot parameter biologi (bakteriologi) dibandingkan kimia dan fisika.

\section{Parameter Tercemar Pada Perairan Pelabuhan Panggulubelo}

Pengukuran Indeks Storet dan Indeks Pencemaran kualitas perairan Pelabuhan Panggulubelo menunjukkan adanya pencemaran ringan dan sedang yang disebabkan oleh parameter yang telah melampaui baku mutu yang diperkenankan. Adapun parameter yang telah melampaui baku mutu kualitas air laut untuk peruntukkan pelabuhan adalah Total Padatan Tersuspensi pada tahun $2013(127,5 \mathrm{mg} / \mathrm{L})$ dan 2016 $(160 \mathrm{mg} / \mathrm{L}), \mathrm{pH}$ pada tahun $2013(8,53)$, serta ammonia pada tahun $2013(8,5 \mathrm{mg} / \mathrm{L})$.

Total padatan tersuspensi (Total Suspended Soid/TSS) adalah bahan-bahan tersuspensi (diameter $>1 \mu \mathrm{m}$ ) yang tertahan pada saringan millipore dengan diameter pori $0,45 \mu \mathrm{m}$. TSS terdiri dari lumpur dan pasir halus serta jasad-jasad renik (Effendi, 2000). TSS terdiri atas lumpur, pasir halus dan jasad-jasad renik, yang terutama disebabkan oleh kikisan tanah atau erosi tanah yang terbawa ke badan air (Nicola, 2015). Gambaran lokasi pada saat pengambilan sampel (2016) menunjukkan bahwa perairan Pelabuhan Panggulubelo dalam kondisi surut. Bahan-bahan tersuspensi di area perairan pelabuhan bisa jadi bersumber dari pasir halus sedimen di areal pasang surut termasuk bahan-bahan organik dari sampah yang dibuang dari pemukiman penduduk di sekitar Pelabuhan Panggulubelo.

Tingginya kadar TSS bersumber dari semua zat padat (pasir, lumpur, dan tanah liat) atau partikel-partikel yang tersuspensi dalam air dan dapat berupa komponen hidup (biotik) seperti fitoplankton, zooplankton, bakteri, fungi, ataupun komponen mati (abiotik) seperti detritus dan partikel-partikel anorganik. Zat padat tersuspensi merupakan tempat berlangsungnya reaksi-reaksi kimia yang heterogen, dan berfungsi sebagai bahan pembentuk endapan yang paling awal dan dapat menghalangi kemampuan produksi zat organik di suatu perairan. Penetrasi cahaya matahari ke permukaan dan bagian yang lebih dalam tidak berlangsung efektif akibat terhalang oleh zat padat tersuspensi, sehingga fotosintesis tidak berlangsung sempurna (Tarigan \& Edward, 2003). Tingginya TSS juga dapat secara langsung mengganggu biota perairan seperti ikan karena tersaring oleh insang. Nilai TSS dapat menjadi salah satu parameter biofisik perairan yang secara dinamis mencerminkan perubahan yang terjadi di daratan maupun di perairan. TSS sangat berguna dalam analisis perairan dan buangan domestik yang tercemar serta dapat digunakan untuk mengevaluasi mutu air, maupun menentukan efisiensi unit pengolahan (Rinawati dkk., 2016).

Tingginya pH pada tahun $2013(8,53)$ kemungkinan dipengaruhi oleh kondisi alkalinitas berupa larutan sedimen batuan karbonat $\left(\mathrm{CO}_{3}^{2-}\right)$ menjadi bikarbonat $\left(\mathrm{HCO}_{3}^{-}\right)$yang bersumber dari limpasan air hujan pada bulan November dari darat di sekitar Pelabuhan Panggulubelo. Kondisi ini dimungkinkan, mengingat secara formasi geologi Wakatobi dikelompokkan ke dalam formasi geologi Qpl dengan jenis bahan induk yaitu batu gamping coral (http://www.wakatobikab. go.id/statik/geografi.daerah/kondisi.geografi.daerah. $\mathrm{html}$ ). Dan batu gamping coral mengandung banyak kalsium karbonat $\left(\mathrm{CaCO}_{3}\right)$ (Noviyanti dkk., 2015). Mackereth et al. (1989) berpendapat bahwa $\mathrm{pH}$ juga berkaitan erat dengan karbondioksida dan alkalinitas. Pada $\mathrm{pH}<5$, alkalinitas bisa mencapai nol. Semakin tinggi nilai $\mathrm{pH}$, semakin tinggi pula nilai alkalinitas dan semakin sedikit kadar karbondioksida bebas.

Toksisitas dari suatu senyawa kimia juga dipengaruhi oleh $\mathrm{pH}$. Senyawa ammonium yang dapat terionisasi banyak ditemukan pada perairan dengan $\mathrm{pH}$ rendah. Ammonium bersifat tidak toksik (innocuous). Pada suasana alkalis ( $\mathrm{pH}$ tinggi) lebih banyak ditemukan ammonia yang tak terionisasi (unionized) dan bersifat toksik. Ammonia tak terionisasi ini lebih mudah terserap ke dalam tubuh organisme akuatik dibandingkan ammonium (Tebbut, 1992). Ammonia yang terukur di perairan berupa ammonia total $\left(\mathrm{NH}_{3}\right.$ dan $\mathrm{NH}^{+}$). Ammonia jarang ditemukan pada perairan yang mendapat cukup pasokan oksigen. Sebaliknya, pada wilayah anoksik yang biasanya terdapat pada dasar perairan, kadar ammonia relatif lebih tinggi. Begitu juga dengan nitrit, nitrit $\left(\mathrm{NO}_{2}\right)$ biasanya ditemukan dalam jumlah yang sangat sedikit. Kadar nitrit pada perairan alami berkisar sekitar $0,001 \mathrm{mg} / \mathrm{L}$ dan sebaiknya tidak melebihi $0,06 \mathrm{mg} / \mathrm{L}$ (PP No. 82 Tahun 2001 dalam Adiansyah V \& Samuel, 2015). 
Sebagian besar biota akuatik sensitif terhadap perubahan $\mathrm{pH}$ dan menyukai nilai $\mathrm{pH}$ sekitar 7 - 8,5. Proses biokimiawi perairan seperti nitrifikasi sangat dipengaruhi oleh nilai $\mathrm{pH}$. Proses nitrifikasi akan berakhir jika $\mathrm{pH}$ bersifat asam. Toksisitas logam memperlihatkan peningkatan pada $\mathrm{pH}$ rendah (Novotny \& Olem, 1994).

Sedangkan tingginya ammonia pada tahun $2013(8,5$ $\mathrm{mg} / \mathrm{L})$ diduga dihasilkan dari proses dekomposisi bahan-bahan organik yang berasal dari wilayah pemukiman masyarakat di sekitar kawasan Pelabuhan Panggulubelo. Ammonia $\left(\mathrm{NH}_{3}\right)$ dan garam-garamnya bersifat mudah larut dalam air. Ion ammonium adalah bentuk transisinya. Sumber ammonia di perairan adalah hasil pemecahan nitrogen organik (protein dan urea) dan nitrogen anorganik yang terdapat dalam tanah dan air, berasal dari dekomposisi bahan organik (tumbuhan dan biota akuatik yang telah mati) yang dilakukan oleh mikroba dan jamur dikenal dengan istilah ammonifikasi (Effendi, 2000). Reduksi nitrat (denitrifikasi) oleh aktivitas mikroba pada kondisi anaerob yang merupakan proses yang umum pada pengolahan limbah juga menghasilkan limbah gas ammonia dan gas-gas lainnya seperti: $\mathrm{N}_{2} \mathrm{O}, \mathrm{NO}_{2}, \mathrm{NO}$, dan $\mathrm{N}_{2}$ (Novotny \& Olem, 1994).

Tinja dari biota akuatik yang merupakan limbah aktivitas metabolisme juga banyak mengeluarkan ammonia. Sumber lain ammonia di perairan adalah reduksi gas nitrogen yang berasal dari proses difusi udara atmosfer, limbah industri dan domestik (Effendi, 2000).

\section{Upaya Mitigasi Pencemaran yang dapat Dilakukan}

Konsentrasi bahan pencemaran perairan di sekitar Pelabuhan Panggulubelo dipengaruhi oleh keberadaan berbagai limbah dari aktivitas di sekitar pelabuhan, seperti aktivitas di area pemukiman yang menghasilkan berbagai limbah domestik, juga dipengaruhi oleh kegiatan yang ada di sekitar area pelabuhan seperti limbah hasil aktivitas kapal.

Kondisi demikian, bila tidak ditangani sejak awal, ke depan akan berpotensi memberikan dampak buruk bagi kualitas perairan dan biota di dalamnya, akibatnya kondisi keseimbangan perairan di wilayah pelabuhan semakin terganggu, di antaranya terancamnya kehidupan sejumlah biota, bahkan mati dan punah, dan dalam jangka panjang dapat mengancam aspek ekonomi dan sosial masyarakat.
Oleh karena itu, diperlukan strategi pengelolaan perairan pelabuhan yang integratif dan kolaboratif dari pihak-pihak terkait, di antaranya: pembenahan fasilitas pelabuhan dalam penanganan sampah, pengendalian sampah dari aktivitas kapal, serta himbauan, pemantauan, dan pengawasan berbagai sumber-sumber sampah dari wilayah pemukiman penduduk di sekitar kawasan Pelabuhan Panggulubelo.

\section{KESIMPULAN DAN SARAN}

Hasil pengukuran terhadap status mutu air laut perairan Pelabuhan Panggulubelo berdasarkan Indeks Storet dan Indeks Pencemaran menunjukkan bahwa perairan laut Pelabuhan Panggulubelo telah mengalami cemaran ringan dan sedang. Kondisi demikian memiliki potensi untuk mengalami pencemaran dengan status tercemar berat bilamana tidak dilakukan upaya yang tepat untuk mengurangi berbagai sumber-sumber pencemaran di area pelabuhan, seperti pengendalian sampah dari pemukiman penduduk dan aktivitas di area pelabuhan.

\section{UCAPAN TERIMA KASIH}

Kami ucapkan terima kasih kepada Kepala Loka Perekayasaan Teknologi Kelautan Wakatobi, Badan Lingkungan Hidup Provinsi Sulawesi Tenggara, dan Dinas Lingkungan Hidup Kabupaten Wakatobi yang telah memberikan dukungan data dalam penyelesaian jurnal ini, serta pihak-pihak lain yang tak sempat disebutkan satu per satu atas bantuannya secara teknis sehingga penelitian dan penulisan jurnal ini dapat terselesaikan.

\section{DAFTAR PUSTAKA}

Adiansyah., V \& Samuel. (2015). Distribusi Oksigen Terlarut dan Beberapa Faktor Fisika dan Kimia Perairan Penting di Danau Lindu Sulawesi Tengah. Aplikasi Teknologi Sebagai Solusi di Bidang Perikanan Secara Berkelanjutan Seminar Nasional Perikanan Indonesia, 19-20 November 2015, STP JAKARTA. ISBN : 978602-72574-5-0.

Anonim. Kondisi Geografi Daerah. http://www.wakatobikab. go.id/statik/geografi.daerah/kondisi.geografi.daerah. html, diakses 20 November 2017.

Bilotta, G.S., \& Brazier, R.E. (2008). Understanding the influence of suspended solids on water quality and aquatic biota. Water Research, 42, 2849-2861.

Dasira, Alyuan. Antara Konsep Kelautan atau Kemaritiman?. http://www.radarbangka.co.id/rubrik/detail/ persepktif/10295/antara-konsep-kelautan-ataukemaritiman.html, dipublikasikan 03 November 2014, diakses 14 Agustus 2017. 
Effendi, H. (2000). Telaahan Kualitas Air-Bagi Pengelolaan Sumberdaya dan Lingkungan Perairan. Jurusan Manajemen Sumberdaya Perairan Fakultas Perikanan dan Ilmu Kelautan, IPB.

Endah, B. R. (2017). Analisis Kualitas Air Laut di Area Alur Pelayaran Barat Surabaya di Selat Madura. Jurnal Rekayasa Sipil dan Lingkungan, ISSN 2548-9518 Vol. 01, No. 01, Januari 2017.

Ermawati, R., \& Hartanto, L. (2017). Pemetaan Sumber Pencemar Sungai Lamat Kabupaten Magelang. Jurnal Sains dan Teknologi Lingkungan Volume 9, Nomor 2, Juni 2017 Hal. 92-104 ISSN:2085-1227 dan e-ISSN:2502-6119.

Hasani, O. U. (2016). Analisis Kualitas Air Sungai Konaweha Provinsi Sulawesi Tenggara. Ecogreen Vol. 2 No. 2, Oktober 2016, Halaman 123 - 129, ISSN 2407 - 9049.

Keputusan Menteri Kehutanan Republik Indonesia Nomor 393/Kpts-IV/1996 tentang Penunjukan Kawasan Kepulauan Wakatobi Dan Perairan Laut Di Sekitarnya Di Kabupaten Daerah Tingkat II Buton, Propinsi Daerah Tingkat I Sulawesi Tenggara Seluas \pm 1.390 .000 (Satu Juta Tiga Ratus Sembilan Puluh Ribu) Hektar Sebagai Taman Nasional.

Keputusan Menteri Kehutanan Republik Indonesia Nomor 7651/Kpts-II/2002 tentang Penetapan Kawasan Kepulauan Wakatobi dan Perairan Laut di Sekitarnya Seluas 1.390.000 (Satu Juta Tiga Ratus Sembilan Puluh Ribu) Hektar.

Keputusan Menteri Negara Lingkungan Hidup Nomor 51 Tahun 2004 tentang Baku Mutu Air Laut untuk peruntukkan pelabuhan.

Keputusan Menteri Negara Lingkungan Hidup Nomor: 115 Tahun 2003 tentang Pedoman Penentuan Status Mutu Air.

Mackereth, F. J. H., Heron, J., \& Talling, J. F. (1989). Water Analysis. Freshwater Biological Association. Cumbria. UK. 120 p.

Muhtadi, A., dkk. (2017). Morfometri dan Daya Tampung Beban Pencemaran Danau Pondok Lapan di Kabupaten Langkat, Sumatra Utara. Oseanologi dan Limnologi di Indonesia 2017 2(2): 49-63.

Nemerow, N. L., \& Sumitomo, H. (1970). Benefits of Water Quality Enhancement. Report No. 16110 DAJ, prepared for the U.S. Environmental Protection Agency, December 1970. Syracuse University, Syracuse, NY.

Nemerow, N. L. (1974). Scientific Stream Pollution Analysis. McGraw-Hill Book Co.

Nicola, F. (2015). Hubungan Antara Konduktivitas, TDS (Total Dissolved Solid) dan TSS (Total Suspended Solid) dengan Kadar $\mathrm{Fe}_{2}^{+}$dan Fe Total pada Air Sumur Gali. (Skripsi). Universitas Jember. Jember.

Ni Ketut Asrini, dkk. (2017). Studi Analisis Kualitas Air di Daerah Aliran Sungai Pakerisan Provinsi Bali. Ecotrophic Volume 11 Nomor 2 TAHUN 2017 p-ISSN: 1907-5626, e-ISSN: 2503-3395.

Noviyanti, dkk. (2015). Karakterisasi Kalsium Karbonat
$\left(\mathrm{Ca}\left(\mathrm{CO}_{3}\right)\right)$ Dari Batu Kapur Kelurahan Tellu Limpoe Kecamatan Suppa. Jurnal Sains dan Pendidikan Fisika. Jilid 11, Nomor 2, Agustus 2015, hal. 169-172.

Novotny, V., \& Olem, H. (1994). Water Quality, Prevention, Identification, and Management of Diffuse Polution. Van Nostrans Reinhod. New York. 1054 p.

Pemerintah Daerah Kabupaten Wakatobi. (2012). Album Peta Rencana Tata Ruang Wilayah Kabupaten Wakatobi.

Perdana, C. (2015). Gambaran Asupan Amonia $\left(\mathrm{NH}_{3}\right)$ Pada Masyarakat Dewasa di Kawasan Sekitar Pemukiman PT. PUSRI Palembang Tahun 2015. (Skripsi). Peminatan Kesehatan Masyarakat Fakultas Kedokteran dan Ilmu Kesehatan Universitas Islam Negeri Syarif Hidayatullah. Jakarta, hal. 14.

Puji, S.S, dkk. (2014). Kajian Bentuk dan Sensitivitas Rumus Indeks PI, Storet, CCME untuk Penentuan status mutu perairan sungai tropis di Indonesia. J. Manusia dan Lingkungan, Vol. 21, No.2, Juli 2014: 129-142.

Rejeki, S. A., dkk. (2014). Status pencemaran dan kandungan logam berat pada simping (Placuna placenta) di Pesisir Kabupaten Tangerang. Depik, 3(2): 91-98 Agustus 2014 ISSN 2089-7790.

Rinawati., Hidayat, D., Suprianto, R., \& Dewi, P. S. (2016). Penentuan Kandungan Zat Padat (Total Dissolve Solid dan Total Suspended Solid) di Perairan Teluk Lampung. Analit: Analytical and Environmental Chemistry Volume 1, No 01, Oktober 2016.

Sarach, S.U., dkk. (2017). Penentuan Status Mutu Air Sungai Berdasarkan Metode Indeks Pencemaran Sebagai Pengendalian Kualitas Lingkungan (Studi Kasus : Sungai Gelis, Kabupaten Kudus, Jawa Tengah). http://ejournal-s1.undip.ac.id/index.php/tlingkungan Jurnal Teknik Lingkungan, Vol. 6, No. 1 (2017).

Setiyo, H.H., dkk. (2009). Analisis Penentuan Mutu Air Beberapa Sungai Di Jawa Tengah Dengan Metode Storet dan Indeks Pencemaran. Jurnal Presipitasi Vol. 6 No.2 September 2009, ISSN 1907-187X.

Sopiani, A. (2014). Menjaga Laut dari Pencemaran dan Perusakan. Mitra Edukasi Indonesia, Bandung.

Sumaji, Awalunikmah, R. (2017). Penentuan Status Mutu Air Sungai Kalimas Dengan Metode Storet Dan Indeks Pencemaran. Undergraduate thesis, Institut Teknologi Sepuluh Nopember Surabaya.

Suwari, dkk. (2010). Penentuan Status Mutu Air Kali Surabaya dengan Metode Storet dan Indeks Pencemaran. Majalah Widya Tahun 27 Nomor 297 Juni 2010.

Tarigan, M. S., \& Edward. (2003). Kandungan Total Zat Padat Tersuspensi (Total Suspended Solid) di Perairan Raha Sulawesi Tenggara, Jurnal Bidang Dinamika Laut, Pusat Penelitian Oseanografi, Makara Sains, 7 (3), 109-119.

Tebbut, T. H. Y. (1992). Principles of Water Quality Control. Fourth Edition. Pergamon Press. Oxford. 251 p.

Undang-Undang Nomor 27 Tahun 2007 tentang Pengelolaan Wilayah Pesisir dan Pulau-Pulau Kecil.

Undang-Undang Nomor 31 tahun 2004 tentang Perikanan. 
